\title{
Pengaruh Model Pembelajaran Kooperatif Tipe Make A Match Terhadap Motivasi dan Hasil Belajar Matematika pada Siswa Kelas VII SMP Yapis Timika
}

\author{
A. Rasul \\ Pendidikan Matematika, STKIP Hermon Timika, Papua \\ email: arasulmtka.unm@gmail.com
}

\begin{abstract}
The problem in learning mathematics at SMP Yapis Timika is that students' motivation and mathematics learning outcomes are low. Furthermore, the teacher never uses the cooperative learning model to make students less enthusiastic in learning. Therefore the aim of this study was to determine the effect of the make a match cooperative learning model on the motivation and learning outcomes of mathematics in class VIIA students of SMP Yapis Timika in academic year 2019/2020. This type of research is experimental research. The experimental design used was a quasi-experimental design with a posttest-only control design. The sampling technique used was purposive sampling where in class VII A was obtained (21 students) as the experimental class and VII B (20- students) as the control class. Based on the results of data analysis, it was found that the average value of students' motivation to learn mathematics in the experimental class with a score of 61.03 in the good category, while the control class got an average score of 57.07 which was categorized quite good. And the experimental class student results data obtained an average score of 81.71 with a success rate of $80.64 \%$. While the control class got an average score of 73.56 with a success rate of $53.33 \%$. And the $t$ test on student learning outcomes obtained $t_{\text {count }}>t_{\text {table }}$ or $3.08>$ 2.01. The results of this study can be concluded, there is an effect of the make a match cooperative learning model on the motivation and learning outcomes of grade VII students of SMP Yapis Timika in academic year 2019/2020.
\end{abstract}

Keywords: Cooperative Learning; Make A Match; Motivation; Student Mathematics Learning Outcome

\begin{abstract}
Abstrak
Permasalahan dalam pembelajaran matematika di SMP Yapis Timika bahwa motivasi siswa dan hasil belajar matematika siswa rendah. Lebih lanjut, guru tidak pernah menggunakan model pembelajaran kooperatif membuat siswa kurang antusias dalam belajar. Oleh karena itu tujuan dari penelitian ini adalah untuk mengetahui pengaruh model pembelajaran kooperatif tipe make a Match terhadap motivasi dan hasil belajar matematika pada siswa kelas VII SMP Yapis Timika tahun akademik 2019/2020. Jenis penelitian ini adalah kuasi eksperimen dengan desain kontrol posttest-only. Teknik pengambilan sampel yang digunakan adalah purposive sampling dimana kelas VII A (21 siswa) sebagai kelas eksperimen dan VIIB (20- siswa) sebagai kelas kontrol. Berdasarkan hasil analisis data didapatkan nilai rata-rata motivasi belajar matematika siswa kelas eksperimen dengan nilai 61,03 dengan kategori baik, sedangkan kelas kontrol mendapat nilai rata-rata 57,07 dengan kategori cukup baik. Kelas eksperimen didapatkan skor rata-rata 81,71 dengan angka keberhasilan 80,64\%. Sedangkan mendapat skor rata-rata 73,56 dengan angka keberhasilan 53,33\%. Dan uji t tentang hasil belajar siswa didapat $t_{\text {hitung }}>t_{\text {tabel }}$ atau 3,08>2,01. Hasil penelitian menunjukkan ada pengaruh model pembelajaran kooperatif tipe make a Match terhadap motivasi dan hasil belajar siswa kelas VII SMP Yapis Timika tahun akademik 2019/2020
\end{abstract}

Kata Kunci: Model Pembelajaran Kooperatif; Make A Match; Motivasi; Hasil Belajar Matematika Siswa 


\section{PENDAHULUAN}

Berdasarkan naskah lampiran peraturan Menteri Pendidikan Nasional nomor 22 tahun 2006 tanggal 23 Mei 2006 mengenai standar isi, disebutkan bahwa pendidikan nasional yang berdasarkan Pancasila dan Undang-Undang Dasar Negara Republik Indonesia Tahun 1945 berfungsi untuk mengembangkan kemampuan dan membentuk watak serta peradaban bangsa yang bermartabat dalam rangka mencerdaskan kehidupan bangsa, bertujuan untuk mengembangkan potensi siswa agar menjadi manusia yang beriman dan bertakwa kepada Tuhan Yang Maha Esa, berakhlak mulia, sehat, berilmu, cakap, kreatif, mandiri, dan menjadi warga Negara yang demokratis serta bertanggung jawab. Untuk mengemban fungsi tersebut, pemerintah menyelenggarakan suatu sistem pendidikan nasional sebagaimana tercantum dalam di dalam Bab I Ketentuan Umum Pasal 1 Undang- Undang Nomor 20 Tahun 2003 tentang Sistem Pendidikan Nasional (Permendiknas dalam Kurnia, 2006:1).

Matematika dengan hakikatnya sebagai ilmu yang terstruktur dan sistematis, serta mengembangkan sikap berpikir kritis, objektif, dan terbuka. Maka dari itu, mengembangkan kemampuan koneksi dan berpikir kritis dalam pembelajaran matematika sangatlah penting (Lestari, 2014:37).

Matematika merupakan salah satu ilmu dasar yang memegang peranan penting baik dalam perkembangan ilmu pengetahuan dan teknologi maupun dalam membentuk kepribadian manusia. Peranan matematika telah merasuk ke semua sendi kehidupan manusia. Matematika sebagai alat bantu telah banyak diaplikasikan untuk mempermudah, mengefektifkan, dan mengefisienkan pekerjaan-pekerjaan manusia. Tetapi, dalam proses pembelajaran matematika terdapat banyak permasalahan. Salah satu permasalahan yang ditemui adalah kurangnya ketertarikan siswa terhadap pelajaran matematika.

Berdasarkan hasil wawancara dengan guru matematika kelas VII SMP Yapis Timika diperoleh informasi bahwa sebagian besar siswa masih kurang termotivasi untuk belajar matematika, dan rendahnya hasil belajar matematika siswa. Selain itu guru matematika kelas VII SMP Yapis Timika masih menggunakan model pembelajaran konvensional dan belum mencoba untuk menggunakan model-model pembelajaran yang baru.

Salah satu cara untuk melihat keberhailan proses belajar mengajar adalah pada hasil belajar siswa. Hasil belajar adalah kemampuan-kemampuan yang dimiliki siswa setelah ia menerima pengalaman belajarnya. Tes hasil belajar adalah sekelompok kepertanyaan atau tugas-tugas yang harus dijawab atau diselesaikan oleh siswa 
dengan tujuan untuk megukur kemampuan belajar siswa. Hasil tes ini berupa data kuantitatif Slameto (dalam Susanti, 2014).

Kingsley (dalam Purnami, 2014:2) mengungkapkan bahwa hasil belajar dibagi menjadi tiga macam, yaitu: keterampilan dan kebiasaan, pengetahuan dan pengertian serta sikap dan cita-cita. Sedangkan Dimyati dan Mudjiono (dalam Wiguna dkk, 2014:2) menyatakan juga bahwa "hasil belajar merupakan hasil dari suatu interaksi tindak mengajar atau tindak belajar"

Salah satu faktor yang dapat meningkatkan hasil belajar matematika siswa adalah motivasi siswa untuk belajar matematika. Apabila siswa termotivasi untuk belajar matematika, maka hasil belajar siswa akan baik pula. Mc Donald (dalam Ekawarna, 2011:52) menyatakan bahwa motivasi adalah perubahan energi dalam diri seseorang yang ditandai dengan munculnya "perasaan/feeling" dan didahului dengan tanggapan adanya tujuan. Brown (dalam Ekawarna, 2011:53), menjelaskan bahwa motivasi adalah dorongan atau rangsangan yang bersifat menyeluruh, situasional, dan berorientasi pada tugas yang digunakan untuk memenuhi kebutuhan. Motivasi belajar adalah hal yang sangat penting dalam proses belajar mengajar. Untuk itu perlu adanya faktor yang membuat siswa menjadi termotivasi untuk belajar matemtika, salah satu faktornya adalah dengan memvariasikan model pembelajaran ketika melakukan kegiatan belajar mengajar. Salah satu model pemebelajaran yang dapat meningkatkan motivasi belajar siswa adalah model pelbelajaran kooperatif tipe make a match.

Lie (dalam Maisari dkk, 2013:2) mengungkapkan bahwa model pembelajaran make a match secara sistematis yaitu guru menyiapkan kartu yang berisi soal-soal dan kartu yang berisi jawabannya, bagi siswa yang mendapatkan sebuah kartu soal berusaha menjawab dan mencari kartu jawaban yang cocok dengan kartu soal yang dimilikinya. Model pembelajaran tipe make a match atau bertukar pasangan merupakan teknik belajar yang memberi kesempatan siswa untuk bekerja sama dengan orang lain. Teknik ini bisa digunakan dalam semua mata pelajaran dan untuk semua tingkatan usia anak didik.

Model pembelajaran make a match atau mencari pasangan dikembangkan oleh Lorna Curran (dalam Huda, 2011:135). Salah satu keunggulan tehnik ini adalah siswa mencari pasangan sambil mempelajari suatu konsep atau topik dalam suasana yang menyenangkan. Menurut Isjoni (2011:112) teknik ini bisa digunakan dalam semua mata pelajaran dan untuk semua tingkat usia anak didik.

Huda (2011:135) mengemukakan prosedur pembelajaran kooperatif tipe make a match:

a) Guru menyiapkan beberapa kartu yang berisi beberapa topik yang cocok untuk sesi 
review (persiapan menjelang tes atau ujian)

b) Guru membagi komunitas kelas menjadi beberapa kelompok. Setiap siswa dalam kelompok, mendapat satu buah kartu.

c) Siswa diberikan waktu untuk mencari pasangan yang mempunyai kartu yang cocok dengan kartunya.

d) Guru dan siswa bersama-sama membuat kesimpulan terhadap materi pelajaran.

Menurut (Huda, 2015:253) kelebihan dari model pembelajaran make a match adalah:

1) Dapat meningkatkan aktivitas belajar siswa, baik secara kognitif maupun fisik

2) Karena ada unsur perminan, metode ini menyenangkan

3) Meningkatkan pemahaman siswa terhadap materi yang dipelajari dan dapat meningkatkan motivasi belajar siswa

4) Efektif sebagai sarana melatih keberanian siswa untuk tampil presentasi

5) Efektif melatih kedisiplinan siswa menghargai waktu untuk belajar.

Dengan menggunakan model ini, guru juga dapat melihat sejauh mana siswa dapat memahami konsep pembelajaran matematika pada model pembelajaran kooperatif tipe make a match.

\section{METODE}

Jenis penelitian yang digunakan pada penelitian ini adalah penelitian eksperimen. Dimana jenis penelitian eksperimen merupakan jenis penelitian yang digunakan untuk mencari pengaruh perlakuan tertentu terhadap suatu kelompok dalam kondisi yang terkendalikan (Sugiyono, 2011:72).

\subsection{Desain Penelitian}

Desain penelitian yang digunakan adalah Quasi Experimental Design dengan jenis Posttest-Only Control Design. Dalam desain ini, siswa diberikan Post-test untuk mengukur hasil belajar setelah pelajaran (Sugiyono, 2011:76).

\subsection{Populasi dan Sampel}

Populasi adalah wilayah generalisasi yang terdiri atas: obyek / subyek yang mempunyai kualitas dan karakteristik tertentu yang ditetapkan oleh peneliti untuk dipelajari dan kemudian ditarik kesimpulannya (Sugiyono, 2011:80). Berdasarkan pendapat di atas, maka yang dimaksud populasi adalah kelas VII SMP Yapis Timika tahun pelajaran 2019/2020. Teknik pengambilan sampel yang digunakan dalam penelitian ini adalah purposive sampling (pertimbangan) adalah teknik pengambilan sampel dengan pertimbangan tertentu (Sugiyono, 2015:124). Sampel pada penelitian ini adalah kelas $\mathrm{VII}_{\mathrm{A}}$ dan $\mathrm{VIII}_{\mathrm{B}}$. 


\section{Mandalika Mathematics and Education Journal \\ Volume 3 Nomor 1, Juni 2020 \\ e-ISSN 2715-1190| | p-ISSN 2715-8292 \\ DOI: http://dx.doi.org/10.29303/jm.v3i1.2592}

\subsection{Instrumen Penelitian}

Instrumen dalam penelitian ini adalah angket motivasi belajar matematika siswa dan lembar tes hasil belajar matematika siswa. Untuk menjamin suatu tes yang disusun tersebut dapat menggambarkan kemampuan siswa dengan tepat maka terlebih dahulu dilakukan uji validitas, reliabilitas, taraf kesukaran (difficulty index) dan uji daya pembeda (discriminating power) dari tes.

\subsection{Teknik Pengumpulan Data}

Teknik pengumpulan data yang digunakan dalam penelitian ini adalah teknik observasi, angket dan data tes hasil belajar matematika siswa.

\subsection{Teknik Analisis Data}

Teknik analisis data pada penelitian ini ada 2 teknik yaitu analisis data kualitatif untuk data lembar observasi keterlaksanaan RPP dan motivasi belajar siswa dan teknik analisis data kuantitatif untuk data hasil belajar, sedangkan uji hipotesis dilakukan dengan menggunakan Uji-t.

\section{HASIL DAN PEMBAHASAN}

\subsection{Hasil Penelitian}

1. Uji coba intrumen

a. Hasil Uji Validitas Soal

Untuk mengetahui kevalidan soal digunakan rumus koefisien korelasi product moment. Berdasarkan hasil uji coba tes dari 25 soal yang diberikan kepada siswa.

Tabel 1. Hasil Uji Validitas Soal

\begin{tabular}{ccccc}
\hline \multirow{2}{*}{ Jumlah Soal } & \multirow{2}{*}{ Valid } & \multirow{2}{*}{ Invalid } & \multicolumn{2}{c}{ Nomor Soal } \\
\cline { 4 - 5 } & \multirow{2}{*}{15} & \multirow{2}{*}{10} & $3,4,5,9$, & $1,2,6,7$, \\
& & & $10,11,1$ & $8,13,15$, \\
& & & $2,14,17$ & $16,18,2$ \\
& & & 19,20, & $2,23,26$ \\
& & & & \\
\end{tabular}

b. Hasil Uji Reliabilitas Soal

Berdasarkan uji reliabiltas yang ditujukan pada Tabel 1 di atas, dari 15 soal yang dinyatakan valid diperoleh rhitung sebesar 0,736 yang menunjukan bahwa soal yang digunakan untuk menjadi instrurn penelitian pada penelitian ini memiliki tingkat reliabilitas yang sangat tinggi. 


\section{c. Hasil Uji Taraf Kesukaran Soal}

Berdasarkan hasil perhitungan tingkat kesukaran soal, masing-masing soal mempunyai tingkat kesukaran yang berbeda-beda dimana ada 5 butir soal yang mudah, 17 butir soal yang sedang dan 3 soal yang sukar.

Tabel 2. Hasil Uji Taraf Kesukaran Soal

\begin{tabular}{cccc}
\hline \multirow{2}{*}{ Jumlah Soal } & \multicolumn{3}{c}{ Nomor Soal } \\
\cline { 2 - 4 } & Mudah & Sedang & Sukar \\
\hline 30 & 5 & 17 & 3 \\
\hline
\end{tabular}

d. Hasil Uji Daya Beda Soal

Dari uji daya beda yang telah dilakukan dari 25 soal, terdapat 2 soal yang memiliki daya pembeda sangat baik, 5 soal dengan daya pembeda baik, 5 soal dengan daya pembeda cukup, 10 soal dengan daya pembeda jelek dan 3 soal dengan daya pembeda negatif .

Tabel 3. Hasil Uji Daya Beda Soal

\begin{tabular}{ccccc}
\hline \multicolumn{5}{c}{ Nomor Soal Dengan Daya Pembeda } \\
\hline Negatif & Jelek & Cukup & Baik & Sangat Baik \\
\hline 3 & 10 & 5 & 5 & 2 \\
\hline \multicolumn{5}{c}{ Jumlah Soal : 30} \\
\hline
\end{tabular}

\section{Hasil Observasi Keterlaksanaan RPP}

Observasi dilakukan setiap kali berlangsungnya pelaksanaan pembelajaran dengan mengamati kegiatan guru dalam proses belajar mengajar. Berdasarkan data yang diperoleh, ketercapai indikator keterlaksanaan RPP untuk kelas Eksperimen sebesar 86,66 \% dengan jumlah skor yang diperoleh adalah 39 dan kategori sangat baik untuk 3 kali pertemuan dan kelas Kontrol sebesar 89,73 \% dengan jumlah skor yang diperoleh adalah 35 dan kategori sangat baik untuk 3 kali pertemuan. Untuk lebih jelasnya dapat dilihat pada Gambar 1.

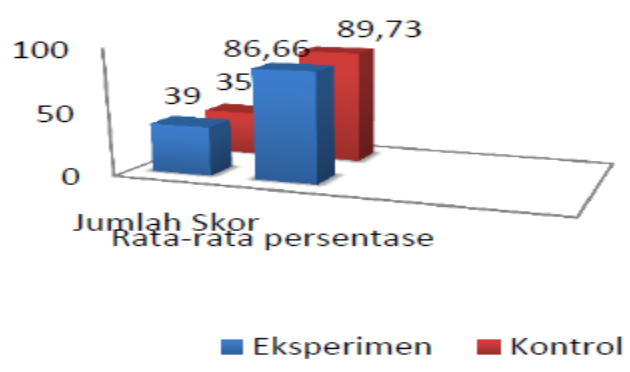

Gambar 1. Grafik observasi keterlaksanaan RPP kelas ekperimen dan kelas kontrol 


\section{Data Motivasi Belajar Siswa}

Berdasarkan data yang diperoleh dapat dilihat bahwa skor rata-rata motivasi belajar matematika siswa untuk kelas eksperimen yang dimana proses belajarnya dengan menggunakan model pembelajaran kooperatif tipe make a match adalah 51,03, dengan jumlah skor yang dicapai adalah 17,92 sehingga dari perolehan nilai rata-rata tersebut kelas eksperimen memiliki kriteria baik dan skor rata-rata motivasi belajar siswa untuk kelas kontrol yang dimana proses belajarnya dengan menggunakan model pembelajaran konvensional adalah 55,07, dengan jumlah skor yang dicapai adalah 16,12 sehingga dari perolehan nilai rata-rata tersebut kelas kontrol memiliki kriteria cukup baik.

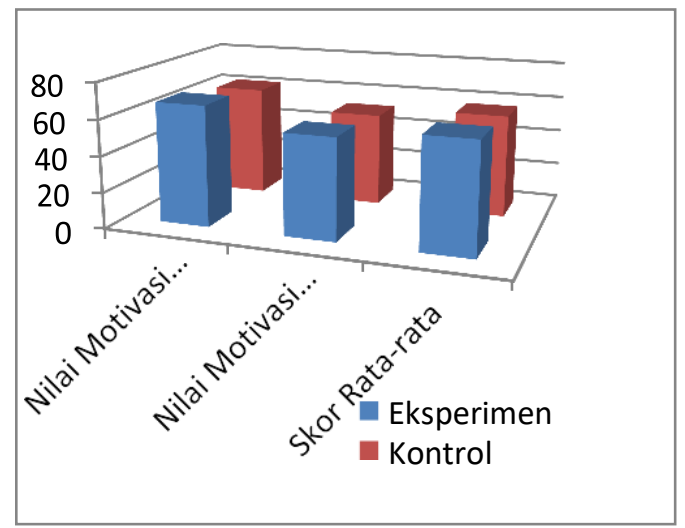

Gambar 2. Grafik perbandingan motivasi belajar siswa kelas ekperimen dan kelas kontrol.

\section{Data Hasil Belajar}

Berdasarkan data nilai tes hasil belajar matematika (posttest) pada kelas eksperimen diperoleh rata-rata kelas 80,71 dengan ketuntasan klasikal 80,54\% dan sedangkan kelas kontrol memiliki nilai rata-rata kelas 73,56 dan ketuntasan klasikal 53,33\%.

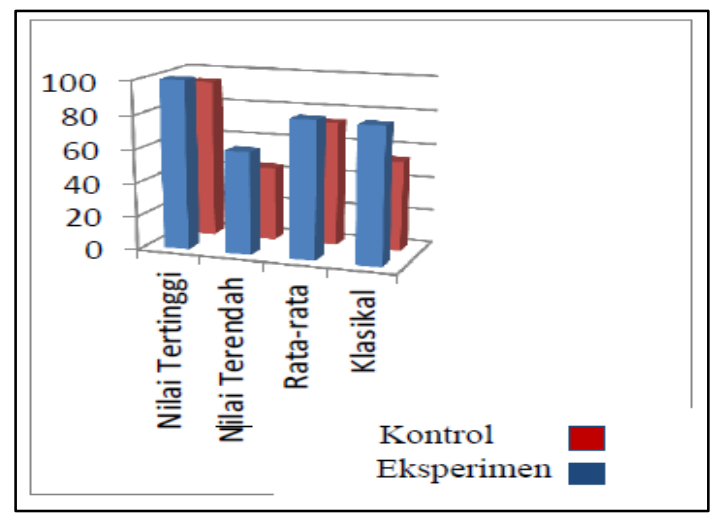

Gambar 3. Grafik perbandingan hasil belajar siswa kelas eksperimen dan kontrol. 
5. Uji Hipotesis

a. Data Hasil Uji Normalitas

Tujuan dilakukan uji normalitas adalah untuk mengetahui apakah data tersebut terdistribusi normal atau tidak. Bedasarkan hasil perhitungan uji normalitas kedua variabel menggunakan rumus uji normaliras, berdasarkan uji normalitas menunjukan hasil belajar pada data posttest kelas eksperimen didapat $\mathrm{X}_{\text {hitung }}<$ $\mathrm{X}_{\text {tabel }}$ atau 4,976 $<9,488$ dan data posttest pada kelas kontrol didapat $\mathrm{X}_{\text {hitung }}<\mathrm{X}_{\text {tabel }}$ yaitu $1,167<9,488$, maka data hasil belajar kelas eksperimen dan kontrol terdistribusi normal.

\section{b. Data Hasil Uji Homogenitas}

Uji homogenitas bertujuan untuk mengetahui seragam tidaknya varians sampelsampel yang diambil dari populasi yang sama. Diketahui bahwa $\mathrm{F}_{\text {hitung }}=1,216$ dan $\mathrm{F}_{\text {tabel }}=1,775$ pada taraf signifikan $5 \%$ dengan $\mathrm{dk}_{\text {pembilang }}=(31-1)=30$ dan $\mathrm{dk}_{\text {penyebut }}=(30-1)=29$ (Terletak antara 28 dan 60), dengan kriteria pengujian yang menyatakan jika $\mathrm{F}_{\text {hitung }}<\mathrm{F}_{\text {tabel }}$ maka sampel dikatakan sama (homogen). Jika hasil di atas dibandingan, terlihat bahwa $\mathrm{F}_{\text {hitung }}<\mathrm{F}_{\text {tabel }}$ yaitu 1,216 $<1,775$ maka dapat dikatakan sampel tersebut homogen.

c. Data Analisis Uji Hipotesis

Untuk mengetahui berpengaruh tidaknya suatu perlakuan atau untuk membuktikan hipotesis yang diajukan maka dilakukan uji hipotesis dengan menggunakan rumus analisis statistik interensial uji-t rumus polled varians digunakan jika data yang dihasilkan homogen, dan rumus separated varians digunakan jika data yang dihasilkan tidak homogen.Uji hipotesis dilakukan untuk mengetahui tingkat hasil belajar.

Tabel 4. Hasil Uji Hipotesis Posttest Kelas Eksperimen dan Kelas Kontrol

\begin{tabular}{cccccc}
\hline Kelas & $\begin{array}{c}\text { Jumlah } \\
\text { Siswa }(\mathrm{N})\end{array}$ & $\begin{array}{c}\text { Rata- rata } \\
(\bar{x})\end{array}$ & $\begin{array}{c}\text { Var ians } \\
(\mathrm{S} 2)\end{array}$ & thitung & t tabel \\
\hline Eksperimen & 21 & 81,71 & 96,68 & 3,08 & 2,01 \\
Kontrol & 20 & 73,56 & 117,64 & & \\
\hline
\end{tabular}

Berdasarkan Tabel 4 didapatkan besar thitung $>t_{\text {tabel }}$ yakni 3,08 $>2,01$ sehingga dapat disimpulkan bahwa hipotesis $\mathrm{H}_{0}$ ditolak dan $\mathrm{H}_{\mathrm{a}}$ diterima. Hal ini berarti bahwa ada pengaruh model pembelajaran kooperatif tipe make a match terhadap motivasi dan hasil belajar siswa kelas VII SMP Yapis Timika tahun akademik $2019 / 2020$. 


\subsection{PEMBAHASAN}

Proses pembelajaran akan berhasil jika adanya faktor yang saling mempengaruhi motivasi belajar siswa salain dari diri sendiri juga diperoleh dari lingkungan belajar seperti guru dan sumber belajar. Jika keduanya saling mempengaruhi maka hasil belajar siswa akan meningkat. Peran guru sangat penting dalam meningkatkan motivasi belajar siswa, antara lain guru dapat menyediakan suasan yang menyenangkan dan dapat mengasah kemampuan siswa selama proses pembelajaran. Untuk itu guru harus pandai memilih model pembelajaran yang sesuai dengan materi pelajaran untuk dapat memperoleh hasil belajar sesuai dengan yang diharapkan.

Pada saat kegiatan belajar mengajar, siswa diberikan perlakuan yang berbeda antara kelas eksperimen dan kelas kontrol. Pada kelas kontrol guru hanya menjelaskan materi dan memberikan latihan kepada siswa, kegiatan tersebut proses pembelajaran yang berlangsung menjadi membosankan dan membuat siswa menjadi pasif selama kegiatan belajar mengajar dan suasana di dalam ruangan kelas tidak menyenangkan.

Sedangkan pada kelas eksperimen guru menjelaskan meteri pelanjaran dan membagi siswa menjadi dua kelompok, dimana kelompok pertama mendapatkan kartu soal dan kelompok kedua mendapatkan kartu jawaban sesuai dengan model pembelajaran make a match (mencari pasangan), Suyatno (dalam Susanti, 2014:31) mengungkapkan bahwa model make a match adalah model pembelajaran dimana guru menyiapkan kartu yang berisi soal atau permasalahan dan menyiapkan kartu jawaban kemudian siswa mencari pasangan kartunya. Pada permainan mencari pasangan guru menuntun mereka untuk mengerjakan soal dan dilanjutkan dengan mencari pasangan dari kartu yang masingmasing mereka miliki sesuai dengan waktu yang ditentukan dan siswa diberi reward apabila menemukan pasangan kartu sebelum waktu yang ditentukan, setelah itu guru menyuruh siswa untuk berdiskusi dengan masing-masing pasangan dan menerjakannya didepan kelas. Kegiatan ini bertujuan untuk memupuk rasa ingin tahu siswa tentang suatu hal yang berkaitan dengan materi pembelajaran, sehingga mendorong siswa untuk berusaha memecahkan masalah, rasa ingin tahu merupakan daya untuk meningkatkan motivasi belajar siswa. Selain itu kegiatan ini guna melihat sampai sejauh mana siswa dapat memahani materi yang dijelaskan dengan cara mengerjakan soal bervariasi yang diberikan oleh guru dengan suasana yang menyenangkan dan dengan kegiatan ini guru juga dapat melihat kemampuan siswa dalam berkomunikasi sesama kelompok ataupun pasangan dari masing-masing siswa yang memiliki kartu.

Salah satu keunggulan tehnik ini adalah siswa mencari pasangan sambil mempelajari suatu konsep atau topik dalam suasana yang menyenangkan (Huda, 2011:135). Apabila didalam ruang kelas tercipta suasana yang menyenangkan maka siswa menjadi lebih termotivasi dalam belajar yang juga berpengaruh terhadap hasil belajar siswa, model 
pembelajaran make a match juga dapat meningkatkan keaktifan siswa selama kegiatan belajar mengajar. Akan tetapi selama kegiatan belajar mengajar dengan menggunakan model pembelajaran make a match membutuhkan banyak waktu sehingga guru harus pandai dalam mengatur waktu selama kegiatan belajar mengajar.

Selama proses belajar mengajar berlangsung, guru menemukan beberapa kendala yang dihadapi, diantaranya masih ada siswa yang belum mentaati jadwal pelajaran, ada beberapa siswa yang mengganggu teman sekelas ketika proses belajar mengajar berlangsung, terdapat siswa yang merasa malu dengan pasangan kelompoknya sehingga mereka enggan untuk berdiskusi bersama, dan adapula siswa yang malu untuk bertanya dan enggan mengerjakan soal latihan yang diberikan. Sehingga dari beberapa kendala tersebut guru harus bisa melakukan pendekatan dengan siswa dan menciptakan suasana kelas yang kondusif.

\section{PENUTUP}

Berdasarkan hasil analisis data dan pembahasan dapat disimpulkan bahwa terdapat pengaruh model pembelajaran make a match terhadap motivasi belajar siswa kelas VII SMP Yapis Timika tahun akademik 2019/2020. Hal ini dapat dilihat dari perolehan nilai rata-rata pada kelas eksperimen yaitu 61,03 sedangkan pada kelas kontrol diperoleh 57,07 dan terdapat pengaruh penggunaan model pembelajaran kooperatif tipe make a match terhadap hasil belajar siswa kelas VII SMP Yapis Timika tahun akademik 2019/2020. Hal ini dapat dilihat dari nilai rata-rata kelas eksperimen 81,71 dengan ketuntasan klasikal $80,64 \%$ sedangkan nilai rata-rata kelas kontrol 73,56 dengan ketuntasan klasikal 53,33\% dan nilai hasil $t_{\text {hitung }}>t_{\text {tabel }}$ yaitu 3,08 $>2,01$.

\section{REFERENSI}

Huda, M. (2011a). Kooperative Learning (Metode, Teknik, Struktur dan Model Penerapan). Yogyakarta: Pustaka Pelajar.

Huda, M. (2015b). Model-Model Pengajaran dan Pembelajaran. Yogyakarta: Pustaka Pelajar. Isjoni, (2014). Cooperative Learning. Bandung: Alfabeta.

Kurnia, R. (2013). Keefektifan model pembelajaran kooperatif tipemake a match terhadap peningkatan hasil belajar matematika pada materi bangun datar siswa kelas III SD Negeri Randugunting 3 Kota Tegal. Skripsi. Universitas Negeri Semarang.

Lestari, K. (2014). Implementasi Brain-Based Learning Untuk Meningkatkan Kemampuan Koneksi dan Kemampuan Berpikir Kritis Serta Motivasi Belajar Siswa SMP. Jurnal Pendidikan Matematika. FKIP UNSIKA. ISSN 2338-2996. 
Maisari, dkk. (2013). Pengaruh model pembelajaran kooperatif tipe make a match terhadap pemahaman konsep matematis (Studi pada siswa kelas VII semester ganjil SMPN 5 Bandar Lampung tahun pelajaran 2012/2013). Jurnal pendidikan matematika. Universitas Lampung.

Purnami, (2013). Peningkatan hasil belajar siswa pada mata pelajaran produktif administrasi perkantoran standar kopetensi mengelola dana kecil kelas XI APK 2 SMK Negeri 1 Surabaya. Jurnal dinas pendidikan kota Surabaya. ISSN: 2337-3253.

Sugiyono, (2011). Metode Penelitian Kuantitatif Kualitatif Dan R\&D. Bandung: Alfabeta.

Sugiyono, (2015). Metode Penelitian Pendidikan (Pendekatan Kuantitatif, Kualitatif dan R\&D). Bandung: Alfabeta.

Susanti, S. (2014). Penerapan Model Pembelajaran Kooperatif Tipe Make A Match Pada Materi Pokok Peluang Sebagai Upaya Meningkatkan Motivasi Dan Hasil Belajar Matematika Siswa Kelas XI MA Al-Umariyah Montong Panjak Praya Tengah. Skripsi. IKIP Mataram.

Wiguna, dkk. (2010). Pengaruh model pemebelajaran kooperatif tipe make a match terhadap hasil belajar matematika siswa kelas IV di gugus III kecamatan Rendang. Jurnal mimbar PGSD. Universitas Pendidikan Ganesha. 